\title{
Epistemic injustice, risk mapping and climatic events: analysing epistemic resistance in the context of favela removal in Rio de Janeiro
}

\author{
Luciana Mendes Barbosa and Gordon Walker \\ Lancaster Environment Centre, Lancaster University, Lancaster, UK \\ Correspondence: Gordon Walker (g.p.walker@lancaster.ac.uk)
}

\begin{abstract}
Received: 7 February 2020 - Revised: 8 September 2020 - Accepted: 21 September 2020 - Published: 12 November 2020
Abstract. Environmental and climate justice scholarship has increasingly focused on how knowledge and expertise play into the production of injustice and into strategies of resistance and activist claim making. We consider the epistemic injustice at work within the practices of risk mapping and assessment applied in Rio de Janeiro to justify the clearance of favela communities. We trace how in the wake of landslides in 2010, the city authorities moved towards a removal policy justified in the name of protecting lives and becoming resilient to climate change. We examine how favela dwellers, activists and counter-experts joined efforts to develop a partially successful epistemic resistance that contested the knowledge on which this policy was based. We use this case to reflect on the situated character of both technologies of risk and the emergence of epistemic resistance, on the relationship between procedural and epistemic justice, and on the challenges for instilling more just climate adaptation strategies.
\end{abstract}

\section{Introduction}

When counter-expert stories are not told, knowledge and hermeneutic injustices emerge. (Williams and Moore, 2019)

Many environmental justice disputes and controversies encompass challenges to both the ways that decisions are made and the forms of knowledge and expertise that are deployed within decision-making processes. Recent scholarship has used the term epistemic justice (Ottinger, 2018; Fricker, 2017; Temper and Del Bene, 2016) to capture critiques of how certain power-laden, knowledge-making practices come to dominate, including to justify actions by the state while others are subjugated and rendered insignificant. While increasing attention has been given to such processes, there is an ongoing need for analysis of particular cases and experiences in order to deepen our understanding of how epistemic questions become refracted through the situated and shifting politics of governance and resistance in different settings. As Klepp and Chavez-Rodriguez (2018) emphasise, climate change has become a particularly significant domain in which knowledge disputes are being played out, including in terms of how assessments of risks, impacts and adaptive potential are being used to justify certain paths of action. There is clear potential for a science-driven, depoliticised discourse of "becoming resilient to climate change" to be used in ways that override local knowledge structures, deepening power differentials and further aggravating historically constituted patterns of inequality and marginality, including in urban settings (Fainstein, 2015; Wakefield, 2018; Kaika, 2017; Grove, 2018).

In this paper, we analyse such themes in relation to the discursive practices of risk assessment applied in Rio de Janeiro to justify the clearance of favelas in the post-2010 period. Favela clearance has a long and deeply controversial history in Rio, extending back to the first half of the twentieth century, with repeated attempts to cast favela dwellers as an illegal, dangerous and unsanitary threat to the urban order and to the modernisation of the city (Perlman, 2006; Soares Gonçalves, 2013; Valladares, 2005). After many contested attempts at favela clearance, in 1988 a major shift in urban policy sought to establish favelas as an integral rather than illegal part of the urban landscape (Soares Gonçalves, 
2006), giving "titling" rights and guarantees to favela residents (Magalhães, 2016). However, a high-profile disaster in 2010 in which heavy rainfall precipitated landslides that killed 67 people gave the city authorities the opportunity to reactivate a key "risk to life" exception to favela integration. They consequently were able to embark on a new programme of clearance in the name of protecting residents from the risk of landslides, including in the context of the intensification of episodes of heavy rainfall under climate change scenarios.

Our objective in this paper is to analyse the manifestation of epistemic injustice in this case and its relation to the politics of epistemic resistance that emerged within threatened favela communities to challenge the basis of the city authorities' apparently expert risk-based decision-making. The term epistemic resistance we take from Medina (2013:3), who refers to it as "the use of our epistemic resources and abilities to undermine and change oppressive normative structures and the complacent cognitive-affective functioning that sustains those structures". We focus on the role of a network of "counter-expertise" that supported the favela dwellers in their fight against the resumption of the removals policy, exposing what Yarina (2018) calls "double-check rhetoric" about climate adaptation or, in other words, the aspects left in the shadows by resilience-building strategies. Through paying attention to the detail of epistemic resistance in this case and the partial success it had in resisting favela clearance, we argue that local knowledge is crucial to mobilisation processes but insufficient on its own to mount an effective challenge to the epistemic and procedural power exercised by the state. Only through coordinating multiple forms of expertise and strategically deploying these in context can the momentum of state-sanctioned processes be interrupted and effective epistemic resistance be deployed.

We begin by positioning our research at the intersection of work on environmental justice, resilience and epistemic resistance. We then explain the research methods applied to the case study and describe the responses to the 2010 disaster that boosted the policy of favela clearance, the risk assessment on which this was based and the initial critiques which emerged. The network of counter-expertise that was integral to contesting the clearance policy is then characterised, before focusing on the case of Estradinha to show how different forms of local, legal and technical knowledge were drawn on and strategically deployed to develop resistance to the city authorities' policy. In the final section, we reflect upon what contributed to the impacts of this resistance and the wider implications for the development of more just processes of climate adaptation.

\section{Justice, disasters and resistance}

As examined within both political ecology and environmental justice literatures, disaster events have generated powerful, multidimensional claims of injustice, making clear the uneven processes and differential vulnerabilities that are implicated across stretched temporal scales (Walker, 2012). In making connections between disasters and climate change dynamics, much recent attention has been given, for example, to the uneven risks and outcomes of flooding, both on its own (Walker and Burningham, 2011) and as part of major hurricanes and storms (Bullard and Wright, 2009; García-López, 2018), and to heat wave events (Mitchell and Chakraborty, 2015; Schlosberg and Collins, 2014). Landslides, the threat to life of concern in this paper, are often also linked to climatic extremes but have been given less attention within environmental justice and related scholarship.

While disaster events reveal and reproduce injustice, strategies for addressing the threat of future disasters have also been critiqued through a justice lens. Discourses of "resilience building", which have become ubiquitous in disaster risk management and related strategies of climate adaptation, have been the subject of a particularly trenchant criticism. Fainstein (2015:157), for example, argues that with resilience "policy makers... are seeking an innocuous label to justify controversial actions" and that power relations and hierarchies are readily obscured. How actions and resources to mitigate risk are socially distributed, how different communities are treated including in terms of who is allowed to stay "in place" and who is removed, and who has the power to shape and influence resilience decision-making are all key justice concerns. Hurricane Katrina in the USA catalysed connections between environmental justice activism and disaster management, with both the relocation of affected residents and decisions about returning to and redeveloping areas at risk controversial in terms of the fractures of race and wealth these processes highlighted (Bullard and Wright, 2009; Morse, 2008). Other cases, for example centred on the impact of sea level rise on low-lying islands, have similarly generated intense debate about the just enactment of consent in relocation strategies for affected communities (Barnett and Campbell, 2009) and the importance of realising relocation in a way that does not destroy senses of community, identity and heritage.

Our case study focuses on strategies of removing so-called "informal" settlements from areas deemed too unsafe for continued habitation and how these can be connected to a broader political intent to clear such settlements from urban spaces. Some equivalent cases have been reported in the literature. Saraçoğlu and Demirtaş-Milz (2014), for example, discuss the case of an "urban transformation project" in Izmir in Turkey, which was carried out to clear a low-income area because of the claimed threat of landslides. They argue that the "naturalising" language of landslide that dominated the project served to conceal its underlying neoliberal logic, as well as the damaging social effects on already marginalised migrant populations, who were removed with little recognition of their needs or livelihoods. Ramalho (2019:1) examining the clearance of low-income settlements in Metro Cebu in the Philippines similarly concludes "that epistemologies 
of modernity, disaster risk and resilience endorsed and propagated by the state are facilitating processes of displacement and dispossession that serve elite commercial interests". Zeiderman's (2012) ethnographic study in Bogotá of how landslide risk became a governmental technology for the clearance of urban slums conceptualises urban risk as a Foucauldian technique of power made possible through probabilistic calculations and mappings. His analysis focuses on the "forms of reasoning and practices with which experts bring threats into frameworks of technical intervention" (Zeiderman, 2012:1575), a focus also in Fraser's (2014) study of the co-production of urban risk in informal settlements in Bogotá, Colombia.

While such work has much to contribute to the understanding of how risk can be deployed as a technology of urban governance, it has focused less substantially on how such clearance strategies can be challenged and resisted. Zeiderman's (2016) study of mobilisation against displacement on marginal coastal land in Buenaventura, Colombia, and Heck's (2016) study of relations between power, knowledge and visual representations of territory in the case of Santa Marta favela in Rio de Janeiro are exceptions and reveal the political discourses and situated context within which quite subtle strategies of defence can be developed. In our analysis we are interested specifically in how risk analyses that serve to normalise the situation of those who are wealthy and have "ontological security" (Fainstein, 2015:158), while exacerbating the insecurity of others who do not, can be counteracted through the development of epistemic resistance. Whilst in the literature on environmental justice there is much enthusiasm for enabling situated lay knowledge on risk to be heard and for involving communities in knowledgemaking processes (Allen, 2018; Camilleri, 2004; Corburn, 2002, 2003; Grineski, 2006; Barandiaran, 2015; Ottinger, 2013), it is not clear if more inclusive epistemic forms can have any meaningful impact on the speed and momentum of high-level decision-making. In such circumstances, strategies of resistance are needed that can make the space for alternative expertise to really count and that can effectively challenge official evidence and discourses within the temporalities of governance processes, including through enrolling professionals as counter-experts in support of environmental justice activism (Ottinger, 2018; Williams and Moore, 2019). In this respect, we see a close relationship between epistemic and procedural justice, with much depending on how legal mechanisms can be utilised by citizens and activists, as well as on how effectively a vocal activism of public protest and dissent can act in support of these.

\section{Methods}

To analyse our case study of attempted favela clearance in Rio de Janeiro, we draw on research undertaken by the lead author over a 7-month period in 2017-2018. Data collection consisted of unstructured interviews with 35 favela dwellers and actors in local activism, semi-structured interviews with policy-makers of the Rio de Janeiro municipality, and extended periods of participant and non-participant observation in six of the favelas that had faced, or were continuing to face, a process of clearance. In this paper, we particularly focus on Estradinha as an example of coordination of resistance to disaster risk displacement. Secondary sources, including government documents, media reports and archives of favela activists, were also integrated into the analysis. All interviews and document extracts have been translated from Portuguese by the first author, and the identity of interviewees has been anonymised unless consent for their identification was given.

\section{Politics of responses to the 2010 landslides in Rio}

The mud and debris that swept through parts of the city slopes in April 2010 led the then mayor, Eduardo Paes, to promise to take decisive action to prevent future catastrophes. A range of steps were initiated, including the setting up of a central emergency coordination room, new weather monitoring systems and infrastructure works, along with a policy of "resettling residents of high-risk areas" (Prefeitura do Município do Rio de Janeiro, 2016). In framing this package of measures the notion of resilience took centre stage, focusing on the shocks and chronic stresses with potential to disrupt the everyday life of the city, or, in the resilience vocabulary, the city's normalcy. According to the Chief Executive of Resilience and Operations, the programme

\section{... despite not presenting any innovative content in itself, brings, as an innovation in the manage- ment of crises and emergencies, an integrated vi- sion of incorporating diverse disciplines to address and respond to chronic and unforeseen shocks, so that, increasingly, society and governments con- sider combining forces to overcome existing chal- lenges and those which have not yet arrived. (Jun- queira, 2015:57)}

The "integrated vision" for the management of crises and emergencies primarily centred on the idea of risk and on "unlikely risks or unknowns" (Prefeitura do Município do Rio de Janeiro, 2014). With particular reference to global warming, it is stated that "the climate is expected to act in an irregular and extreme manner", which means that, according to the new vision for city planning, "too much reliance on historical data can lead to mistaken predictions that do not take into account the unpredictability of nature and human actions". In the Visão Rio 500, a long-term plan for the next 50 years, the stated intent is that "the city will be ready and adapted to face climate change and its impacts, having mapped and planned for its main threats" such that "no family in the city will be living in situations of high physical vulnerability" (Prefeitura do Município do Rio de Janeiro, 
2016). However, the key question is how these situations are to be determined and through what means the apparent risk to life is to be managed.

In 2010 the municipality moved fast to lay out the arguments for a large-scale and rapid programme of evictions. As the mayor stated, the time has arrived "to end the demagogy and remove the houses in risky areas" (Globo, 2010), seizing the opportunity to announce the launch of a "large package of removals":

We will not do works of $\$ 3$ million to ensure some houses stay in place. It would be better to give an apartment in Barra for each household, which is cheaper, and no one dies. The removals will continue in my government and soon we will announce a large package of removals in areas of risk.

Very rapidly, a list was released identifying 21000 houses in 117 communities as at risk of succumbing to landslides and in need of clearance, with eight favelas facing complete demolition. This list was presented as based on a scientifically undertaken assessment and mapping of risk by the GeoRio Foundation (Geo-Rio). Established in 1966, the legal responsibilities of Geo-Rio included the elaboration of emergency and long-term plans for the protection of the slopes and the execution of slope containment works. Risk mapping by Geo-Rio had been undertaken from 1984, their work making favelas visible for the first time in the official cartography of the city. As a kind of "unconquered territory, a terrae incognitae, favelas had been silenced in many of Rio de Janeiro's maps over the last century" (Novaes, 2014:201), and it is not coincidental that they became officially legible first through the lens of risk. By 2010 Geo-Rio had developed its landslide risk mapping methodology considerably, assessing different areas as having a low, moderate or high risk (dos Santos, 2009) with the logic of optimising the allocation of public resources.

Backed up by expert science, the speed of the announcement of the clearance programme constituted a "politics of emergency" (Honig, 2009), driven by the apparently noble objective of preserving life. A number of authors have portrayed the shift into a politics of emergency as a moment in which increased precarity can be forced onto populations (Klein, 2007; Bracke, 2016; Massumi, 2009). Honig (2009), however, recognises that official declarations of emergency can be both a way of imposing new forms of control and discipline and an opportunity for marginalised and excluded groups to reassess unfair situations and develop alternative political responses and strategies. As an interviewee made clear, the alignment of risk and emergency has potentially powerful effects: "the technical argument of risk ... practically nullifies all the other rights" such that in the context of a supposed imminent disaster, "you cannot speak of the right to housing of a person who lives in a place where the hill will fall". However, the condition of emergency was not accepted as such, with the list of clearance areas immediately interpreted by favela residents as a product of ongoing anti-favela politics, rather than being based on a disinterested and objective technical assessment. As an interviewee noted, the technical risk argument was deployed "to fulfil a demand that the mayor had already presented" in the first strategic plan of the municipality produced soon after he took over the City Hall in 2009, in which he pledged to reduce by at least $3.5 \%$ the area of favelas in the city by 2012 compared to 2008 (Prefeitura do Município do Rio de Janeiro, 2012). For the interviewee, the 2010 disaster, therefore, presented an opportunity for the mayor "to make an immediate and impressive impact" and speed up the removal of favelas regardless of their risk categorisation.

As critics pointed out, the list of areas designated for clearance after the 2010 disaster included three communities that were not identified as "high-risk areas" in previous technical mapping assessments. The list also excluded any upper- or middle-class areas despite these having been also affected by the landslides in 2010. The emblematic case used to point out evident inconsistencies in the city authorities' response was the mansion of the then Secretary of Housing, Urban Planning and Infrastructure. This property was partially swallowed by mud and rocks in 2010, but given its location in one of the five most expensive neighbourhoods in the city, the Alto Jardim Botânico, it was not included in the list of areas to be cleared. Meanwhile, close to the property, the Horto favela was assigned as a "high-risk area" scheduled for clearance, and local inhabitants reported that the Civil Defense of the State of Rio de Janeiro ignored the property in undertaking inspections after the landslide event. As one interviewee ironically commented, "we are talking about rich areas, not risk areas".

This unjustifiably differentiated risk management policy was therefore readily interpreted as playing both into longstanding attempts to find reasons for removing favelas from the city and into the deep differentials of wealth and power that run through the city's history and ongoing politics (Costa, 2018; Mendes, 2016; Soares Gonçalves, 2015). Revealingly, in an interview undertaken with a staff member of Geo-Rio, it was all but accepted that the risk assessment was undertaken in a way that privileged the interests of those in the "formal city". As they acknowledged "the pressure from the formal city is higher; that is, they pay more taxes, they are better able to fight and such. But there is no legislation saying the risk and such for that place. This is an implicit, conspicuous thing; it's there, everyone knows, but you can't make it clear". This emblematic example confirms the acute relevance of Fraser's (2014) observation that "the practices of risk assessment, despite their technical construction, embody not a value-free science, but one imbued with a set of particular political values." 


\section{The network of counter-expertise}

Thousands of favela residents were therefore faced with the consequences of a resilience strategy that was actively targeting their right to 'stay put' (Hartmann, 1984) and sustain their communities in place. The sense of threat and injustice this presented was intensified by failure of the city authorities to follow designated procedures for when the 'risk exception' is applied to favela clearance. The municipal law of 1992 specifies that

the municipality must (a) present a technical report of the responsible body; (b) ensure the participation of the community of interest and representative entities in the analysis and definition of solutions; and (c) guarantee settlement in localities near the places of housing or work, if removal is necessary. (Lei Orgânica do Município, 2010)

Whilst a technical risk report was released (after some delay), there was no attempt by the city authorities to enable participation or to guarantee nearby resettlement. An interviewee commented that it was not at all surprising that this process had been ignored, given that Brazil "has very good laws, a seemingly very advanced constitution, but deep down it works in a mafia state, where all these rights on paper are derogated in practice". Faced therefore with an entwined distributional and procedural injustice, the favela dwellers had to act fast and across many different fronts to resist their removal. While this resistance took various forms, including conventional modes of public demonstration and lobbying, we focus here on the epistemic resistance that pushed back against the powerful locking together of technical expertise and the moral case for protecting life.

The drawing together of "epistemic resources and abilities" (Medina, 2013:3) centred on a network of counterexpertise - summarised in Fig. 1 - which mobilised a combined profile of local, legal and technical knowledge.

This network was embedded in a longer history of mobilisation by favela communities to protect their rights to housing. In the post-2010 period, there were two key bodies whose expertise became particularly important: first, the Conselho Popular (People's Council), an assembly of favela leaders, activists and residents that brought situated, local knowledge into the development of resistance strategies, alongside legal and technical expertise. The Conselho Popular was formed in 2007 to defend against the first attempted favela removal after Brazil's re-democratisation, focused on a small favela located in Jacarepaguá, in the West Zone of the city. The city authorities argued that favela removal was needed because of flood risks, and to challenge this the Coletivo Técnico (Technical Collective) was established within the Conselho Popular, specifically to scrutinise the risk arguments mobilised by the city authorities. As we shall see, this group, consisting of architects, geographers and engineers, became particularly crucial in the post- 2010 period in devel-

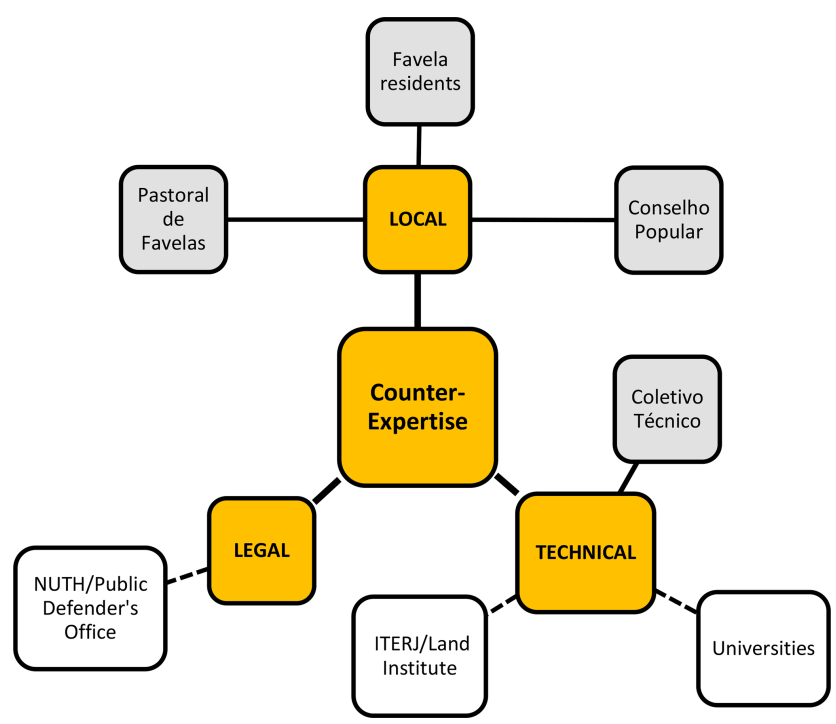

Figure 1. The structure of the counter-expertise network.

oping alternative technical reports and evidencing conditions on the ground. The second key organisation was the Land and Housing Division (Núcleo de Terras e Habitação - NUTH), linked to the Public Defender's Office of the State of Rio de Janeiro (the state level being distinct from municipal city governance), which has the role of providing legal expertise to citizens on housing and land issues and has the ability to challenge municipal-level decisions in the courts.

Further organisations with more of a background role included the Pastoral de Favelas, a branch of the church formed in 1976 during the early phases of the democratisation of Brazil (Gay, 1999; Brum, 2005), which has acted as a "structuring institution in support of the Conselho Popular" (Costa, 2018:26). Conselho Popular meetings are often held at its premises and involve the lawyer of the Pastoral de Favelas, who works closely with the public lawyer from the NUTH. Technical expertise is also drawn from the Land and Cartography Institute (ITERJ), a state-level authority linked to the Rio de Janeiro State Environment Secretariat, which assesses claims made by favela residents for legal rights to residence and carries out surveys of infrastructural conditions. This evidence can often be important in legal challenges taken forward by the NUTH. The local universities in Rio have also become involved in supporting favela activism, usually through extension projects contributing, for example, architectural, planning, engineering or sociological expertise to projects co-producing knowledge with favela residents.

In the 2010 period, this network of counter-expertise acted to resist attempted clearance across multiple favelas, working in necessarily flexible and responsive ways to the needs of particular communities. In the next section, we will examine the case of Estradinha, tracing how different forms of local, legal and technical knowledge were drawn on and strategically deployed. 


\section{Strategies of epistemic resistance in Estradinha}

Estradinha is a small favela located in Botafogo, an otherwise wealthy neighbourhood in the South Zone of the city. According to interviewees, the first residents arrived in the area in 1952, when 19 families of employees of the São João Batista cemetery were settled with the support of a charity responsible for managing the cemetery. The favela is located on the lower and middle parts of the hillside, behind what is now a large cemetery area. In 1986, Mayor Saturnino Braga allowed an additional 42 families to settle in Estradinha by donating lots and "construction kits" to residents that did not have resources to build their homes. Over the years, Estradinha did not significantly expand its territory horizontally, but vertical growth took place with the addition of further storeys to existing buildings. By 2009, the community consisted of 335 households and approximately 1600 residents.

In 2010, Estradinha was included in the city authorities' list of eight favela communities for complete clearance, and actions began to be taken very rapidly directed towards that end, with a number of residents deciding to take the money on offer from the city authorities to relocate (although on terms which were later criticised as misleading). Once residents had moved out, their homes were rapidly demolished by contractors working for the city authorities to prevent any reoccupation. For the residents who chose to remain during this first phase of intervention, their experience of living in Estradinha opened up immediate contradictions with the official risk narrative and acted as an important catalyst for their coming together and mobilisation. Angélica, an older resident of the favela, describing herself as "just a housewife", emerged as a community leader. In an interview discussion, she referred to how impacts on the nearby cemetery of the rains of 2010 became "weaponised" to condemn the whole community as a high-risk area:

When it came to the rains of 2010, in April, the risk was throughout the city of Rio de Janeiro. The rain did not affect only the hills; it affected the entire city. There was flooding everywhere... And here in the community, the only thing that fell into the cemetery was a fusquinha [an old Volkswagen Beetle] that had been abandoned for a long time and a flow of mud covering some graves. There was no damage even on the street.... And because of that blockage that fell inside the cemetery, Mayor Eduardo Paes ... caught everyone and put them in the pack.

\section{[Interviewer] Claiming?}

[Angélica] Claiming that the whole community was at risk.

Angélica also contrasted her experience of the labour of building her house and knowing the local geology with the very distant, remotely sensed satellite data that fed into the assessment process that was being used to justify removals:

This house was built upon a bedrock. This house is in the bedrock! From below, you go inside the cemetery and see the huge rock that is there. So, I know this house will never fall!... And the soil here is Saibro [a name given by the locals] ... hard, we sometimes had to cut with a pick to get where we wanted. The only intention of the City Hall was to remove the community. Every time I met Bit$\operatorname{tar}$ [the then Secretary of Housing] we argued, because he used to say, 'I have a satellite that looked down from above, made a survey and found that the terrain is slippery'. Then, I said, but I have a satellite called my hand that dug the holes to build my house and found that the ground is firm. So, your satellite is crazy.

In these encounters, Angélica directly challenges the epistemic authority of the satellite, arguing that her own situated and embodied understanding of the geophysical features of her community was much better formed. She had experience not only of building her own house but also of being part of the mutirão (favela dwellers' "joint effort") through which she used her practical skills to help construct other houses in the community.

Another example of local experience opening up evident contradictions in what the city authorities were claiming centred on the setting up of the Pacifying Police Unit (Unidade de Polícia Pacificadora - UPP) in the area classified as "high risk" by Geo-Rio. As observed by Doralice, another resident,

You say that it is a risk area and that a rock will roll from above, it will tear down the houses; then comes the UPP and occupies this same place. If you're in a risky area, how are you going to put a lot of police officers there, a lot of people, a lot of humans, lives.... What if the rock falls and kills everyone? Oh, it's a lie! You started to see that all this is a lie, that's when we started [the process of resistance].

While such experiences and observations motivated resistance to the clearance policy, it was recognised that to have any impact on decision-making processes, a more overtly "professional" and credible challenge to official policy needed to be developed. As highlighted by one of the interviewees from the NUTH, experience had shown that local knowledge is persistently marginalised, especially in relation to environmental issues, and that therefore the strategy had to be to challenge the city authorities' expertise on its own terms in order to try to defend the residents' right to stay put.

The technical expertise of the Coletivo Técnico therefore became crucial. The Estradinha residents first went to the NUTH to ask them to obtain a copy of the technical assessment by Geo-Rio that underpinned the decision to re- 
Table 1. Challenges to the official assessment of risk included in the Coletivo Técnico report.

\begin{tabular}{|c|c|}
\hline Aspects highlighted or omitted by Geo-Rio's report & Response by the Coletivo Técnico engineer \\
\hline $\begin{array}{l}\text { (A) Based on comparison of aerial photographs taken } \\
\text { in } 1999 \text { and 2008, the favela's territorial expansion } \\
\text { has caused environmental damage in the area, } \\
\text { resulting in a higher risk to the residents occupying } \\
\text { this expanded area. }\end{array}$ & $\begin{array}{l}\text { Based on the comparison of the area occupied by the } \\
\text { community in different periods }(1999,2004 \text { and } \\
\text { 2008), there was no significant expansion of } \\
\text { Estradinha's area. As with many of the consolidated } \\
\text { favelas in the city, the expansion of Estradinha was } \\
\text { mostly vertical in adding new additional storeys to } \\
\text { existing buildings. }\end{array}$ \\
\hline $\begin{array}{l}\text { (B) The entire community is in an area of high } \\
\text { geological technical risk because of the presence of } \\
\text { rocky outcrops and deposits of talus in the area } \\
\text { upstream of the community. There is a risk of these } \\
\text { rocks falling and reaching residences. }\end{array}$ & $\begin{array}{l}\text { The deposits of talus and rocky outcrops are located } \\
\text { only in the eastern portion of the community and on } \\
\text { the southern boundary, where there were only } 30 \\
\text { houses potentially affected. This is not a risk to the } \\
\text { entire community. }\end{array}$ \\
\hline $\begin{array}{l}\text { (C) There are limited containment works that reduce } \\
\text { risks. }\end{array}$ & $\begin{array}{l}\text { There are a series of containment works carried out } \\
\text { by the residents themselves which are not included in } \\
\text { the Geo-Rio report. These retaining walls are often } \\
\text { grounded in the bedrock, which considerably reduces } \\
\text { the risk of landslides. }\end{array}$ \\
\hline
\end{tabular}

move their favela. The Conselho Popular then asked an engineer from the Coletivo Técnico to undertake an "on-theground" technical survey which assessed the evidence and claims made in the Geo-Rio report, through inspecting areas where landslides had occurred, evaluating the likelihood of further landslides and checking the integrity of the main existing containment works. Table 1 summarises some of the key criticisms of the Geo-Rio risk assessment that featured in the report produced by the engineer.

The counter-report delivered to the NUTH in June 2010 concluded overall that the high-risk designation had no justification and that "there is no technical or economic basis in this proposed removal", providing a direct and substantiated challenge to the evidential foundation of the city authorities' actions.

The next step was not however to take this challenge forward into the courts but to slow down the city authorities' actions by developing evidence focused on poor demolition practices. The first "voluntary" phase of removing residents who were prepared to accept the city authorities' monetary offer had left behind partly destroyed buildings and piles of rubble. This meant that in "preventing risk" new risks were generated for the residents who were still in place. A specific further report on these problems was written by a group of residents and submitted to the NUTH, arguing that

We believe that the intention of this municipal government is to "let the community die" and create a state of defencelessness where the only way out is the spurious negotiation for the release of the area for real estate purposes. The situation is really serious, since in the rainy season what can happen to this rubble that is obstructing channels and places where water seeps? We also fear what will happen to these "skeletons" of houses that currently house rats and flies... No to terrorist removal by city hall. (Estradinha's blog cited by Mendes, 2016)

Responding to the demands of residents, the NUTH then commissioned a second survey by a sanitary engineer from a public health institute, again to provide expert credibility for their claims. This confirmed bad demolition practices, including leaving behind obstructions to access roads used by service providers, damage to rainwater drainage system and exposed electricity cables (Mendes, 2016).

This focus on evidencing what the city authorities were doing in the first phase of clearance was strategically important for building an effective strategy of resistance against subsequent removals. An interview with one of the members of the Coletivo Técnico made clear that there were significant difficulties in getting the technical challenges to the official risk assessment to count in the courts, however well founded and evidenced they were, given that the courts routinely deferred to the apparently authoritative expertise of Geo-Rio:

Even the NUTH had a very good idea that due to the guidance of the judiciary it was very risky to file lawsuits. Actions had a very good chance of being dismissed, and that was indeed true of some. For example, in the Pavão-Pavãozinho case, the judge says, 'oh no! I don't understand the technical argument, but the city has competent bodies so if it claims that, I have faith that's right'. 
In order to circumvent the likelihood that the legal process would simply ignore challenges to the risk assessment that underpinned the logic of removal, the NUTH advised focusing on more objective and immediate problems. A lawsuit was successfully taken forward focused on the problems caused by the first wave of demolitions, with the court judgement determining that the residents who had not elected to move out of the favela deserved proper "public consideration". The city authorities were instructed to undertake the "removal of debris resulting from actions taken by the municipal government within 5 days, subject to a daily fine of R \$50,000.00", and crucially they also had to immediately suspend all further demolitions until this work was completed.

While the counter-reports therefore fed into carefully chosen legal challenges, they were also used as political instruments by the favela dwellers. One of the interviewees from the Coletivo Técnico, when asked about the destination of the counter-reports produced for not just Estradinha but also other favela communities, answered that "most of the reports I made - I would not say most, but more than half of them - were not used as a court case, but they were used politically by the communities. They would take it and go to the City Hall meeting with the report in hand". Recognising this potential in the counter-reports, the interviewee stated that he "was trying to make reports readable to people", without giving up the technical precision that they needed. The accessible language of the reports and the intense process of knowledge exchange between counter-experts and communities they enabled were important in making it possible for favela dwellers to use the reports to "attack bureaucratic rules" (Parthasarathy, 2010), including the city authorities' failure to follow the procedural requirements required by the municipal law when the "risk to life" argument was activated.

The favela communities and supporting organisations therefore applied pressure on multiple fronts. In Estradinha, with any further demolitions temporarily stopped, the intensity of criticism of the designation of the whole community as a high-risk area eventually led to a new assessment of risks by Concremat, a company outsourced by Geo-Rio to update their risk assessment. Their report produced in November 2010 came to conclusions that were very similar to those of the engineer from the Coletivo Técnico, identifying only 25 houses in Estradinha in a "high-risk" area. For this reason, the report concludes that "in 2010, on the basis of a risk inventory, it was found that the community continues to have a low existing risk for the most part" (Geo-Rio and Concremat, 2010). The removals process was consequently suspended, with 100 households from the 325 originally in place remaining standing, a partial success at least in resisting the city authorities' plans.

\section{Conclusion}

The favela clearance policy announced in Rio in 2010 constituted for many critics just the latest manifestation of attempts to remove favelas from the landscape of the modern, neoliberal city and its "worlding" ambitions (Ramalho, 2019). That it was justified through a rhetoric of, and a legal provision for, making the city more resilient to disaster (and to climate change) demanded that resistance focused on the specific substance of the resilience argument - its epistemic foundation - rather than longer-standing arguments defending the settlement rights of favela residents. For the logic of removal to be challenged, the favelados who insisted on staying in place had to do far more than rely on their understanding of the local environment, based in observation, historical knowledge and embodied experience, however rich and informed that might be. Strategies of epistemic resistance needed to be developed which had some bite. This involved deploying the skills and experience of members of the Coletivo Técnico to dismantle the official assessment of disaster risk; legally demanding, through people's lawyer (NUTH) compliance with the rule of law by the city authorities, evidencing and challenging its failure to follow proper procedure; and using knowledge produced by the counter-experts combined with the favelados' own lived experience in order to exert public political pressure on the city authorities. Through a combination of these intertwined strategies, the injustice of the favelados' communities being falsely claimed to be at high risk was challenged and resisted. The outcome was the successful interruption of the process of favela clearance in Estradinha and other favelas, slowing down, or even blocking, one of the largest cycles of attempted removals in the city's history.

In articulating this case with arguments and observations in the wider literature, we can make four more general points. First, as other studies of disaster risk displacement have found (Ramalho, 2019; Saraçoğlu and Demirtaş-Milz, 2014; Heck, 2016), the context within which technologies of risk are applied is crucial to their politicisation and their material consequences for targeted communities. While risk assessment and mapping may therefore appear to be a "portable" set of universal techniques (Walker, 2009), reproduced unproblematically from case to case, in practice they become grounded in a way that makes them subject to local norms of governance and extant fractions of political power. Second, the potential for epistemic resistance to develop in a way that can challenge the power-knowledge of official assessments of risk is similarly contextualised. In learning from a case in which there was some degree of success, it is important, therefore, to recognise the many years of mobilisation this built on, including crucially the counter-expertise that was already in place and ready to act. It would be naïve, therefore, to imagine its straightforward reproduction in other settings, even if lessons can be learnt from interrelated strategies that were deployed. While therefore it might be argued in 
Foucauldian terms that wherever "there is power-knowledge there is epistemic resistance" (Allen, 2017:192), the form that resistance takes and the agency it comes to command is very much situated and a matter for empirical investigation. Third, our case suggests that the relationship between epistemic resistance and procedural justice merits more attention in environmental justice scholarship. The celebration of local experiential knowledge needs to be tempered by the struggles involved in making this really count. In practice, as Allo (2020) has argued, the courtroom can be an important site of epistemic resistance, as can other venues within which procedures are enacted and counter-knowledge can, in principle, be heard. Understanding more about how the procedural and the epistemic aspects work together is therefore an important trajectory for future research.

Finally, along with many others our case study highlights the importance of arguing for fair, transparent and democratic disaster risk reduction and climate adaptation policy (Morchain, 2018), through which actions in the name of becoming resilient to climatic extremes cannot be pursued without due scrutiny, debate, inclusivity and prioritisation of the needs of those most affected (Klepp and ChavezRodriguez, 2018). The democratisation of local responses to climate impacts (Mikulewicz, 2018) is all the more vital where displacements and resettlements are proposed, given the violence that can be enacted through these processes on people's lives. There is though little prospect of such "just adaptation" policy emerging in contexts where rights to land and property have been long disputed, decision-making procedures are readily corrupted or ignored, and power hierarchies are deeply embedded. The need for effective strategies of epistemic resistance to be developed in the face of such injustice is clear and likely to become ever more important as the potential escalates for appropriation of climate resilience justifications for the pursuit of elite interests.

Data availability. The underlying research data for this paper were collected under guarantees that they would be only be used for the purpose of $\mathrm{PhD}$ research (by the first author) and associated publication. Confidentiality considerations mean that they cannot be made available for public access. Any queries regarding data and their interpretation should be directed to the authors.

Author contributions. LMB undertook the empirical research and analysis and the writing of the original draft. GW contributed to developing the conceptual framing and to reviewing and editing the discussion.

Competing interests. The authors declare that they have no conflict of interest.
Acknowledgements. We would like to thank all those who generously gave their time in participating in the research and also Giovanni Bettini for his advice and guidance and the two reviewers for their insightful comments.

Financial support. This work was supported by CAPES (Higher Education Personnel Improvement Coordination; Brazil) under a grant for $\mathrm{PhD}$ research for Luciana Mendes-Barbosa. She was also supported through an IJURR Foundation writing-up grant.

Review statement. This paper was edited by Silja Klepp and reviewed by two anonymous referees.

\section{References}

Allen, A.: Power/Knowledge/Resistance: Foucault and Epistemic Injustice, in: The Routledge Handbook of Epistemic Injustice, edited by: Kidd, I. J., Medina, J., and Pohlhaus, G., Routledge, Abingdon, 187-194, 2017

Allen, B. L.: Strongly Participatory Science and Knowledge Justice in an Environmentally Contested Region, Sci. Technol. Hum. Val., 43, 947-971, 2018.

Allo, A. K.: The Courtroom as a Site of Epistemic Resistance: Mandela at Rivonia, Law Cul. Human., 16, 127-150, 2020.

Barandiaran, J.: Chile's environmental assessments: contested knowledge in an emerging democracy, Sci. Cult., 24, 251-275, 2015.

Barnett, J. and Campbell, J.: Climate Change and Small Island States: Power, Knowledge and the South Pacific, Earthscan, London, 2009.

Bracke, S.: Bouncing Back, in: Vulnerability in Resistance, edited by: Butler, J., Gambetti, Z., and Sabsay, L., Duke University Press, Durham, NC, 52-75, 2016.

Brum, M.: "Despertar e incentivar"! A Pastoral de Favelas e o movimento comunitário de favelas cariocas na Redemocratização, Revista Cantareira, Revista Eletrônica de História, 2, 3, available at: http://www.historia.uff.br/Cantareira (last access: 10 March 2019), 2005.

Bullard, R. and Wright, B. (Eds.): Race, Place and Environmental Justice after Hurricane Katrina, Westview, Boulder, 2009.

Camilleri, M.: From the inside looking out: knowledge, justice and modernity in the assessment of St. Julian's environmental capacity, Local Environ., 9, 45-63, 2004.

Corburn, J.: Combining community-based research and local knowledge to confront asthma and subsistence-fishing hazards in Greenpoint/Williamsburg, Brooklyn, New York, Environ. Health Perspect., 110, 241-248, 2002.

Corburn, J.: Bringing local knowledge into environmental decision making: Improving urban planning for communities at risk, J. Plan. Educ. Res., 22, 420-436, 2003.

Costa, M.: Experiências de resistência à remoção em territórios ocupados pela população pobre nas periferias da cidade do Rio de Janeiro, in: Revista Libertas, Juiz de Fora, v. 18, p 191-228, jan. a jul. de 2018, available at: https://libertas.ufjf.emnuvens.com.br/ libertas/index (last access: 21 June 2019), 2018. 
dos Santos, M. C.: O discurso técnico do risco nas tentativas recentes de remoções forçadas de favelas no Rio de Janeiro, Seminário URBFAVELAS, Rio de Janeiro, 2009.

Fainstein, S.: Resilience and Justice, Int. J. Urban Reg. Res., 39, 157-167, 2015.

Fraser, A.: Rethinking Urban Risk and Adaptation: The Politics of Vulnerability in Informal Urban Settlements, PhD Thesis, London School of Economics, London, available at: http://etheses. lse.ac.uk/3130 (last access: 30 August 2019), 2014.

Fricker, M.: Evolving concepts of epistemic injustice, in: The Routledge Handbook of Epistemic Injustice, edited by: Kidd, I. J., Medina, J., and Pohlhaus, G., Routledge, Abingdon, 53-60, 2017.

García-López, G. A.: The Multiple Layers of Environmental Injustice in Contexts of (Un)natural Disasters: The Case of Puerto Rico Post-Hurricane Maria, Environ. Just., 11, 101-108, 2018.

Gay, R.: The Broker and the Thief: A Parable (Reflections on Popular Politics in Brazil), University of Wisconsin Press, Madison, 1999.

Geo-Rio and Concremat: Relatório de campo - Ladeira dos Tabajaras, Geo-Rio, Rio de Janeiro, 2010.

Globo, J. O.: Prefeitura removerá 119 favelas até o fim de 2012, available at: https://oglobo.globo.com/rio/ prefeitura-removera-119-favelas-ate-fim-de-2012-3072053 (last access: 1 November 2019), 2010.

Grineski, S. E.: Local struggles for environmental justice: Activating knowledge for change, J. Poverty, 10, 25-49, 2006.

Grove, K.: Resilience, Routledge, Abingdon, 2018.

Hartman, C.: The Right to Stay Put, in: Land Reform, American Style, edited by: Geisler, C. and Popper, F., Rowman \& Allanheld, Totowa, NJ, 302-319, 1984.

Heck, C. L.: Informal Urban Displacement in Rio de Janeiro: Ecolimits and Disaster Biopolitics in the Favela Santa Marta, FIU Electronic Theses and Dissertations, available at: https: //digitalcommons.fiu.edu/etd/2987 (last access: 16 June 2020), 2016.

Honig, B.: Emergency politics: paradox, law, democracy, Princeton University Press, Princeton, NJ, 2009.

Junqueira, P.: Da consciência à resiliência?: o novo papel do poder público e do cidadão na construção de uma cidade resiliente, Cadernos Adenauer, Rio de Janeiro, 57-75, 2015.

Kaika, M.: 'Don't call me resilient again!': the New Urban Agenda as immunology ... or ... what happens when communities refuse to be vaccinated with 'smart cities' and indicators, Environ. Urban., 29, 89-102, 2017.

Klein, N.: The Shock Doctrine: The Rise of Disaster Capitalism, Metropolitan Books, Durham, 2007.

Klepp, S. and Chavez-Rodriguez, L. (Eds.): Governing Climate Change: the power of adaptation discourse, policies and practices, in: A Critical Approach to Climate Change Adaptation: Discourses, Policies and Practices, Routledge, Abingdon, 1-32, 2018.

Lei Orgânica do Município: Procuradoria - Geral do Município do Rio de Janeiro, 2. ed. rev. e ampl., Centro de Estudos da Procuradoria-Geral do Município, Rio de Janeiro, p. 224, 2010.

Magalhães, A. F.: O direito das favelas, FAPERJ - Letra Capital, Rio de Janeiro, 2016.

Massumi, B.: National Enterprise Emergency: Steps Toward an Ecology of Powers, Theor. Cult. Soc., 26, 153-185, 2009.
Medina, J.: The Epistemology of Resistance: Gender and Racial Oppression, Epistemic Injustice, and the Social Imagination, Oxford University Press, New York, https://doi.org/10.1093/acprof:oso/9780199929023.001.0001, 2013.

Mendes, A.: O debate em torno do risco, da moradia e das remoções em um ano de tragédias, in: A Resistência à remoção de favelas no Rio de Janeiro : instituições do comum e resistências urbanas: a história do núcleo de terras e habitação e a luta contra a remoção de favelas, edited by: Mendes, A. and Cocco, G., Editora Revan, Rio de Janeiro, 2016.

Mendes, A.: O debate em torno do risco, da moradia e das remoções em um ano de tragédias, in: A Resistência à remoção de favelas no Rio de Janeiro: instituições do comum e resistências urbanas: a história do núcleo de terras e habitação e a luta contra a remoção de favelas, edited by: Mendes, A. and Cocco, G., Editora Revan, Rio de Janeiro, 2016.

Mikulewicz, M.: Politicizing vulnerability and adaptation: on the need to democratize local responses to climate impacts in developing countries, Clim. Dev., 10, 18-34, 2018.

Mitchell, B. C. and Chakraborty, J.: Landscapes of thermal inequity: disproportionate exposure to urban heat in the three largest US cities, Environ. Res. Lett., 10, 115005, https://doi.org/10.1088/1748-9326/10/11/115005, 2015.

Morchain, D.: A critical approach to climate change adaptation, in: A Critical Approach to Climate Change Adaptation: Discourses, Policies and Practices, edited by: Klepp, S., and ChavezRodrigues, L., Routledge, Abingdon, 2018.

Morse, R.: Environmental Justice through the Eye of Hurricane Katrina, Joint Center for Political and Economic Studies, Health Policy Institute, Washington, D.C., 2008.

Novaes, A. R.: Favelas and the divided city: Mapping silences and calculations in Rio de Janeiro's journalistic cartography, Social Cult. Geogr., 15, 201-225, 2014.

Ottinger, G.: Changing Knowledge, Local Knowledge, and Knowledge Gaps, Sci. Technol. Hum. Val., 38, 250-270, 2013.

Ottinger, G.: Opening Black Boxes: environmental justice and injustice through the lens of science and technology studies, in: The Routledge Handbook of Environmental Justice, edited by: Holifield, R., Chakraborty, J., and Walker, G., Routledge, Abdingdon, 2018.

Parthasarathy, S.: Breaking the expertise barrier: Understanding activist strategies in science and technology policy domains, Sci. Publ. Policy, 37, 355-367, 2010.

Perlman, J. E.: The Metamorphosis of Marginality: Four Generations in the Favelas of Rio de Janeiro, Ann. Am. Acad. Polit. Social Sci., 606, 154-177, 2006.

Prefeitura do Município do Rio de Janeiro: Plano Estratégico Da Prefeitura Do Rio De Janeiro 2009-2012, avaialable at: http://www.rio.rj.gov.br/dlstatic/10112/6616925/4178940/ planejamento_estrategico_site_01.pdf (last access: 26 February 2019), 2012.

Prefeitura do Município do Rio de Janeiro: Rio Resiliente: Diagnóstico e Áreas de Foco, available at: http://centrodeoperacoes.rio/ assets/PEF-0112-14-LVR-210x280-Resiliencia-43.pdf (last access: 15 April 2020), 2014.

Prefeitura do Município do Rio de Janeiro: Decreto Rio n 42599, Prefeitura Municipal do Rio de Janeiro, Rio de Janeiro, 2016. 
Ramalho, J.: Worlding aspirations and resilient futures: Framings of risk and contemporary city-making in Metro Cebu, the Philippines, Asia Pacific Viewpoint, 60, 24-36, 2019.

Saraçoğlu, C. and Demirtaş-Milz, N.: Disasters as an ideological strategy for governing neoliberal urban transformation in Turkey: Insights from Izmir/Kadifekale, Disasters, 38, 178-201, https://doi.org/10.1111/disa.12038, 2014.

Schlosberg, D. and Collins, L. B.: From environmental to climate justice: climate change and the discourse of environmental justice, WIREs Clim. Change, 5, 359-374, 2014.

Soares Gonçalves, R.: La politique, le droit et les favelas de Rio de Janeiro Un bref regard historique, J. Anthropologues, 104/105, 37-63, 2006.

Soares Gonçalves, R.: A política, o direito e as favelas do Rio de Janeiro : um breve olhar histórico, URBANA: Revista Eletrônica Do Centro Interdisciplinar de Estudos Sobre a Cidade, 1, 1-23, 2013.

Soares Gonçalves, R.: "São as águas de março fechando o verão ...": chuvas e políticas urbanas nas favelas cariocas, Acervo, 28, 98-119, 2015.

Temper, L. and Del Bene, D.: Transforming knowledge creation for environmental and epistemic justice, Curr. Opin. Environ. Sustain., 20, 41-49, 2016.
Valladares, L. P.: A invenção da favela: do mito de origem a favela.com, available at: https://editora.fgv.br/produto/ a-invencao-da-favela-do-mito-de-origem-a-favela-com-1702 (last access: 1 May 2019), 2005.

Wakefield, S.: Infrastructures of liberal life: From modernity and progress to resilience and ruins, Geogr. Compass, 12, e12377, https://doi.org/10.1111/gec3.12377, 2018.

Walker, G.: Beyond distribution and proximity: exploring the multiple spatialities of environmental justice, Antipode, 41, 614-636, 2009.

Walker, G.: Environmental Justice: Concepts, Evidence and Politics, Routledge, Abingdon, 2012.

Walker, G. and Burningham, K.: Flood Risk, Vulnerability and Environmental Justice: evidence and evaluation of inequality in a UK context, Crit. Social Policy, 31, 216-240, 2011.

Williams, L. D. A. and Moore, S.: Conceptualizing Justice and Counter-Expertise, Sci. Cult., 28, 251-276, 2019.

Yarina, L.: Your Sea Wall Won't Save You, Places Journal, https://doi.org/10.22269/180327, 2018.

Zeiderman, A.: On shaky ground: The making of risk in Bogotá, Environ. Plan. A, 44, 1570-1588, 2012.

Zeiderman, A.: Submergence: Precarious Politics in Colombia's Future Port-City, Antipode, 48, 809-831, 2016. 